\title{
FUNGSI BADAN USAHA MILIK DESA (BUMDES) SARI AMERTHA SUDHA SIDAKARYA DALAM MENINGKATKAN KESEJAHTERAAN MASYARAKAT DESA
}

\author{
Putu Gede Putra Dharma Yasa, Ida Ayu Putu Widiati, I Wayan Arthanaya \\ Fakultas Hukum Universitas Warmadewa, Denpasar-Bali, Indonesia
}

\begin{abstract}
Abstrak
Bumdes adalah suatu pendekatan baru yang bertujuan untuk meningkatkankesejahteraan bagi masyarakat desa dalam menggali potensi yang di miliki oleh desa. Bumdes di kelola oleh desa dan di bantu dengan masyarakat desa. Permasalahan yang ada dalam penelitian ini; bagaimanakah pengelolaan bumdes berdasarkan UU No. 6 Tahun 2014 tentang Desa, Bagaimanakah efektivitas bumdes Sari Amertha Sudha Sidakarya dalam meningkatkan kesejahteraan masyarakat. Penelitian ini merupakan penelitian empiris dengan pendekatan sosial. Untuk pengelolaan BUMDes harus di jalankan menggunakan prinsip kerja sama, keterlibatan, emansipasi, tidak di tutupi, terhitung dan berkelanjutan. Dalam implementasi pengelolaan BUMDes, ada tiga hal yang harus diperhatikan, yaitu tentang penguatan kapasitas pengelolaan BUMDes, laporan dan administrasi keuangan BUMDes, dan pengembangan unit usaha. Maka arah kebijakan pembinaan BUMDes berfokus pada upaya fasilitasi pengembangan SDM, penguatan kelembagaan, peningkatan akses modal, dan advokasi kebijakan yang dirumuskan berdasarkan skala prioritas. Efektivitas bumdes Sari Amertha Sudha dalam upaya meningkatkan kesejahteraan bagi masyarakat desanya dengan melalui penembangan ekonomi. Bentuk partisipasi masyarakat untuk ikut dalam pengembangan BUMDes yaitu ikut membuat perencanaan, ikut serta dalam upaya pengelolaan bumdes dan ikut memonitoring dan mengevaluasi bumdes Sari Amertha Sudha Sidakarya.
\end{abstract}

Kata Kunci: Fungsi BUMDes, Kesejahteraan Masyarakat, Pengelolaan BUMDes, Waserda.

\begin{abstract}
Bumdes is a new approach that aims to improve the welfare of the village community in exploring the potential that the village has. Bumdes is managed by the village and assisted by the village community. The problems that exist in this research; how is the management of bumdes based on Law no. 6 of 2014 concerning Villages, how is the effectiveness of Sari Amertha Sudha Sidakarya in improving community welfare. This research is an empirical research with a social approach. The management of BUMDes must be carried out using the principles of cooperation, involvement, emancipation, not being covered up, calculated and sustainable. In implementing BUMDes management, there are three things that must be considered, namely strengthening the management capacity of BUMDes, BUMDes financial reporting and administration, and developing business units. Therefore, the direction of BUMDes development policy focuses on efforts to facilitate human resource development, strengthening institutions, increasing access to capital, and advocating for policies formulated based on priority scales. The effectiveness of bumdes Sari Amertha Sudha in an effort to improve the welfare of the village community through economic development. The form of community participation to participate in the development of BUMDes is to participate in planning, participate in efforts to manage bumdes and participate in monitoring and evaluating bumdes Sari Amertha Sudha Sidakarya.
\end{abstract}

Keywords: BUMDes Function, Community Welfare, BUMDes Management, Waserda.

\section{PENDAHULUAN}

Pasal 1 ayat (3) Undang-Undang Dasar Negara Republik Indonesia Tahun 1945 (UUD NKRI 1945) menegaskan bahwa Indonesia adalah negara hukum. Pasal 1 ayat (3) menyebutkan bahwarakyat merupakan pemegang kekuasaan tertinggi dalam membentuk suatu tata hukum untuk membangun sebuah negara, bukan hanya itu sebagai negara hukum menegaskan bahwa hukum merupakan jalan utama yang akan mengatur hidup masyarakat, berbangsa, dan bertanah air. Indonesia ingin menciptakan masyarakat yang adil dan makmur yang didasari oleh Pancasila.

Sebagai negara hukum, maka segalakehidupan yang ada di masyarakat, maupundari apa yang di lakukan oleh pemerintah harus didasarkan oleh hukum yang sudah ada di Indonesia. Salah satu upaya untuk menciptakan negara yang berlandasakan hukumadalahdengan membuat peraturan-peraturan dan penatan instansi. Oleh karena itu, undang-undang berperan penting dalam melakukan 
pembangunan sebuah negara dan merupakan pilar untuk menjalankan pemerintahan baik itu pusat, daerah, dan desa. Untuk mengetahui setiap peraturan perundang-undangan yang telah di kerjakan sesuai dengan Undang-Undang dasar maka di bentuk UUDNRI Tahun 1945 yang berhubungan dengan apa tugas dan kewenangan dalam menguji sebuah peraturan perUndang-Undangan yang telah di buat (Soekanto, 2000).

Undang-Undang Desa berdasarkan pasal-pasal yang terdapat pada UUD 1945 berkaitan dengan pemerintahan daerah, tetapi yang sangat berhubungantentang desa adalah pada Pasal 18 B ayat (2) UUDNRI 1954 yaitu: Negara menerima dan menghargaikeberadaanmasyarakat adat, hukum adatnya, dan berserta tradisi tradisi yang masih ada di masyarakat dan di sesuaikan dengan prinsip negara yang sudah di atur dan di muat dalam Undang-Undang.Dalam Undang-Undang Desa berisi tentang Batasan wilayah antara desa dan desa adat yang memiliki wilayah yang lebih luas. Desa merupakan suatu perkumpulan masyarakat, yang memiliki batas wilayah, memiliki tradisi, ada hak asal usul, memiliki pemerintah desa dan membangun untuk mengurus pemerintahan desa, yang dihargai dan ada dalam system pemerintah di Indonesia.

Menurut PP No 43 Tahun 2014tentang Peraturan Pelaksana UU No 6 Tahun 2014 tentang Desa pada Pasal 83 berisi tentang, rancangan peraturan desa di buat oleh pemerintahan desa, dan BPD bisa mengajukan usulan dan merancang peraturan desa. Rancangan peraturan desa wajib disampaikan kepada masyarakat desa untuk mendapatkan masukan, dan setelah disepakati bersama kemudian rancangan peraturan desa di tetapkan menjadi peraturan desa yang disampaikan oleh pimpinan BPD kepada kepala desa, terhitung paling lambat satu minggu dimulai dari tanggal perjanjian. Peraturan desa dianggap sah mulai di perundang undangkan oleh Lembaga desa (Huda, 2015).

Salah satu tujuan pemerintah adalah membangun daerah pedesaan agar produktvitas meningkat dan beberapa usaha di desa, adanya sarana dan fasilitas yang dapat meningkatkanpendapatan desa, memperkuat rantai kreasi dan penjualan, serta menciptakan kesejahteraan masyarakat untuk membangun pendapatan desa. Tujuannyayaitu untuk melihat apa yang dimiliki desa yang menjadi tujuan utama desa akan menjadi tulang punggung untuk meningkatkan perekonomian yang ada di desa. Pembangunan pedesaantidak hanya fokus pada pengembangan sumber daya manusia, namun unsur ekonomi dan pembangunan fisik juga penting. Pengembangan Desa adalahtolak ukur dari pengembangan Nasional, karena jika suatu desa sanggup melaksanakan pengembangan ekonomi secara mandiri, dapat mencapai kemakmuran masyarakat dan juga bisa meningkatkan kesejahteraan masyarakat desa (Mubyarto \& Kartodirdjo, 1988).

Dengan adanya Undang-undang nomor 6 tahun 2014 yang membahas tentang desa dapat menjadi kesempatan bagi setiap desa agar dapat meningkatkan potensi desa untuk mendapatkan apa yang dibutuhkan masyarakat desa. BUMDes adalah suatu organisasi atau lembaga yang didirikan pemerintah desa yang modalnya diberikan dan dikelola oleh pemerintah dan dibantu juga oleh masyarakat desa. Pembentukan BUMDes dilandasi atas adanya kebutuhan dan potensi desa dalam upaya memperkuat perekonomian serta membangun kesejahteraan masyarakat desa.

Salah satu desa di Bali yang sudah menerapkan BUMDes adalah Desa Sidakarya. Desa Sidakarya membangun WASERDA (warung serba ada). WASERDA itu sendiri adalah sebuah kegiatan usaha sejenis warung yang menjual berbagai kebutuhan pokok masyarakat, dengan harga yang lebih murah. Dimana nantinya WASERDA bisa berperan sebagai supplier untuk warungwarung kecil yang ada di Desa Sidakarya. Ini adalah salah satu contoh program yang sudah dijalankan oleh BUMdes Sidakarya, dimana terdapat program-program baru yang bisa direalisasikan lagi, untuk lebih meningkatkan kesejahteraan masyarakat khususnya dalam bidang ekonomi.

Dengan adanya BUMDes, diharapkan agar masyarakat Desa Sidakarya lebih aktif berpartisipasi untuk mengsukseskan program ini. Diharapkan nantinya program ini dapat menjadi peluang bagi masyarakat Desa Sidakarya untuk meningkatkan perekonomian, karena secara tidak langsung program ini akan membuka banyak lapangan pekerjaan. Selain itu, diharapkan warung - warung kecil yang ada di Desa Sidakarya bisa lebih mudah untuk mencari alternatif supplier, dengan memanfaatkan WASERDA yang ada.

Berdasarkan pemaparan diatas, penelitian ini difokuskan pada pembahasan proses pembangunan kesejahteraan masyarakat melalui BUMDes serta mengetahui partisipasi masyarakat dalam membantu pengembangan kesejahteraan masyarakat desa. Oleh karena itu, penelitian ini bertujuan untuk menganalisis pengelolaan BUMDes berdasarkan Undang-Undang No. 6 Tahun 2014 tentang desa dan 
menganalisis efektivitas BUMDes Sari Amerta Sudha Sidakarya dalam meningkatkan kesejahteraan masyarakat.

\section{METODE PENELITIAN}

Penelitian ini menggunankan metode penelitian Empiris (Ishaq, 2017; Sunggono, 2006). Adapun sumber data utamanya adalah data sekunder yang berupa bahan hukum, baik berupa bahan hukum primer, sekunder, maupun tersier (Soekanto, 1986). Penelitian ini menggunakan metode studi kepustakaan adalah dengan merujuk kepada bahan-bahan yang didokumentasikan, sedangkan alat yang dipergunakan adalah studi dokumen, yaitu studi dengan cara mempelajari bahan hukum baik berupa buku, laporan hasil penelitian, makalah seminar, tulisan para ahli, dan semua peraturan yang berkaitan dengan materi penelitian. Setelah bahan-bahan hukum terkumpul, selanjutnya diolah dan dianalisis dengan menggunakan penafsiran hukum yang kemudian disajikan dalam bentuk deskriptif analisis untuk memberikan gambaran secara umum.

\section{HASIL DAN PEMBAHASAN}

BUMDes adalah suatu organisasi atau lembaga yang didirikan pemerintah desa yang modalnya diberikan dan dikelola oleh pemerintah dan dibantu juga oleh masyarakat desa. Pendirian BUMdes menurut Undang-Undang No. 32 Tahun 2004 tentang pemerintahan daerah bertujuan untuk meningkatkan pendapatan asli desa. Jika BUMDes dapat membantu penghasilan desa, akan memberika dorongan bagi pemerintah desa untuk memberikan keuntungan untuk membangun BUMDes. BUMDes diharapkan mampu memiliki ciri has tersendiri dari Lembaga ekonomi pada umumnya. Ini bertujuan supaya BUMDes dapat memberikontribusi yang positif dan signifikanbagi pegembangan dan peningkatan kesejahteraan masyarakat. Selain itu, agar tidak muncul usaha kapitalis di desa yang dapat mengganggu kehidupan bermasyarakat (Departemen Pendidikan Nasional Pusat Kajian Dinamika Sistem Pembangunan (PKDSP), 2007).

BUMDes didirikan untuk desa untuk kesejahteraan masyarakat desa, dan diharapkan desa dapat mengejar ketertinggalan dari beberapa desa yang ada di Indonesia. Adanya BUMDes, memberikan kesempatan pada masyrakat untuk menggali, mengelola, dan mengembangkan potensi sumber daya yang ada di desa sesuai dengan kebutuhan, serta mampu menjadi pusat kebutuhan masyarakat desa dan menjadi tempat bagi desa lain untuk ikut berkembang. Badan Usaha Milik Desa (BUMDes) memiliki empat tujuan, yaitu:

a. Mengembangkanekonomi desa

b. Mengembangkan penghasilan asli desa

c. Mengembangkan potensi yang dimiliki desa berdasarkan keperluan masyarakat

d. Menjadi penunjangpeningkatan dan untuk meratakan ekonomi pedesaan.

Demi mendapatkan suatu tujuan yang di inginkan oleh BUMDes, maka bisa di lakukan dengan langkah-langkah sepeti bisa memenuhi keperluan masyarakat dalam kehidupan sehari-hari seperti menjadi distributor bagi masyarakat setempat. Diharapkan upaya yang dilakukan ini tidak membebani masyrakat, di karenakan kedepannya BUMDes akan menjadi pusat dimana masyarakat akan di penuhi kebutuhan hidupnya dan bisa merasakan kesejahteraan di dalam desa dan demi meningkatkan pendapatan desa. BUMDes tidak harus juga memberikan pelayanan kepada masyarakat desa. Namun, BUMDes juga bisa memberikan pelayanan yang sama kepada masyarakat lainnya dengan ketetapanketetapan yang sudah di buat seperti misalnya harga dan pelayanan, maka tidak meyebabkan ketidaksesuaian ekonomi di desa yangdi karena kan adanya usaha yang dijalankan BUMDes. Dalam Undang-Undang disebutkan BUMDes didirikan berdasarkan apa yang diinginkan oleh masyarakat dan kemampuan desa. Menurut (Wijaya, 2018), yang di maksud dengan yang diinginkan oleh masyarakat dan kemampuan desa ialah:

a. Memenuhi kebutuhan masyarakat

b. Adanya sumber daya yang masih dapat di kelola

c. Tersedianya SDM dari masyarakat untuk membangkitkan pendapatan desa

d. Menambahkan unit-unit usaha untuk masyrakat agar membuka lapangan kerja yang lebih luas.

Pemerintah desa terlibat sebagai pendiri dan penyedia modal awal. Dengan bantuan masyarakat BUMDes di harapkan dapat memenuhi kebutuhan mayarakat. Maka dari itu, pemerintah desa sangat penting ada dalam membentuk BUMDes agar semua yang di lakukan berdasarkan hukum yang 
berlaku dan serta tidk bertentangan dengan masyarakat (Poerwadarminta, 1975). Prinsip Tata Kelola Badan Usaha Milik Desa (BUMDes), yaitu:

a. BUMDes di kelola dengan menerapkan prinsip kooperatif, partisipatif, emansipasif, transparansi, akuntable, dan sustainable, di harapkan dengan menerapkan prinsip tersebut bisa menjadikan lebih dewasa dalam pengelolaan. Maka dari itu, untuk membangun BUMDes perlunya informasi yang terjamin kebenarannya.

b. BUMDesberdiri karena adanya keinginan masyarakat yang dimana modal dari pendirian tersebut berasal dari masyarakat dan pemerintah desa. NamunBUMDes bisa saja mendapatkan modal dari pihak lain, dari PEMKAB bahkan bisa mengajukan pinjaman modal kepada pihak ketiga, yang di dasarkan dengan peraturan yang telah di tetapkan.

c. BUMDes dibangun berdasarkan tujuan yang pasti. Nantinya tujuan itu akan direalisasikan dengan cara melakukan aktivitas layanan kebutuhan usaha yang produktif yang diprioritaskan untuk warga kurang mampu di desa, menciptakan peluang kesempatan berwirausaha dan menambahkan penghasilan masyarakat. Dan BUMDes diharapkan bisa menjadi pelajaran bagi masyarakat agar lebih terbiasa menyisihkan penghasilannya untuk investasi kedepan, agar terciptanya pengembangan ekonomi yang lebih mandiri.

d. BUMDes tidak akan terlepas dari pihak luar yang tidak hanya memberikan pengaruh bagi masyarakat desa, namun juga bagi masyarakat di kabupaten. Oleh karena itu pendirian BUMDes harus lebih dipikirkan tentang adanya sumber daya desa yang lebih baik dan mendukung, system pajak, dan ketataan masyarakat dalam menjalankan kewajibannya.

e. Diprediksi bahwa yang menjadi prioritas untuk mendapatkan layanan utama BUMDes diantaranya a). warga desa yang memenuhi keperluan hidup, yang mata pencarian di bidang tani dan sedang menjalankan bisnis yang tidak resmi. b) warga desa yang memiliki pendapatandi bawah rata-rata dan belum bisa membagi pendapatannya sebagai uang pokok atau modal untuk mendirikan sebuah usaha. c) warga desa yang keperluan hidupnya belum tercapai dan lebih memilih bekerja dengan pebisnis. d) warga desa yang memiliki bisnis namun disulitkan dengan marketing.

Kata efektivitas berasal dari kata dasar efektif dalam bahasa latin efficere yang berarti memunculkan, atau menemukan hasil. Dalam Kamus Besar Bahasa Indonesia, efektivitas di artikan sebagai hasil akibat, dalam situasi berhasil atau sesuatau yang dapat menghasilkan atau menimbulkan. Maka dari itu efektivitas hukum dapat diartikan sebagai akibat hukum, atau keberhasilan pelaksanaan hukum itu sendiri. Efektivitas adalah pengukuran hasil yang di dapat dari masukan yang digunakan dalam menyelesaikan pekerjaan sesusai dengan waktu, tujuan dan sasaran yang telah ditetapkan. Menurut (Soekanto, 2008), efektivitas suatu hukum dapat di lihatdaribagaimana masyarakat menaati aturan aturan yang ada, danjuga bagaimana aparat yang menegakan aturan tersebut. Jadi ketaatan terhadap suatu aturan dapat menjadi indikasi berfungsi atau tidaknya aturan yang telah di tetapkan. Berfungsinya suatu aturan menandakan bahwa apa yang telah diinginkan atau di tentukan memenuhi target yang di inginkan hukum tersebut. Berusaha mempertahankan dan melindungi masyarakat dalam pergaulan hidup merupakan suatu tujuan dari fungsi hukum.

Efektivitas berdasrkan apa yang ada di atas dapat diartikan bahwa indikasi efektivitas dalam arti tercapainya sasaran dan tujuan dari apa yang diinginkan sebelumnya telah tercapai dengan apa yang diinginkan berdasarkan apa yang direncanakan. Kesimpulannya bahwa efektivitas merupakan penanaman yang multi, yang mengartikan efektivitas tidaklah semua sama karena bisa diartikan berbeda beda sesuai dengan apa yang dibahas dan tujuannya.

Efektivitas BUMDes Sari Amertha Sudha yaitu mensejahterakan masyarakat desa sidakarya. Upaya yang dilakukan pemerintah dalam meningkatkan kesejahteraan bagi penduduk desa. Maka dengan hadirnya BUMDes Sari Amertha Sudha dipercaya dapat meningkatkan kesejahteraan bagi penduduk desa. Tetapi beberapa BUMDes tidak dapat mencapai tujuan dari BUMDes tersebut. BUMDes Desa sidakarya merupakan salah satu BUMDes yang masih berjalan dengan baik. Bentuk pengelolaan yang telah di lakukan BUMDes yaitu membangun usaha Waserda. Waserda itu sendiri adalah warung serba ada. Pengelolaan Waserda ini perlu ditingkatkan kembali pengelolaanya. Tidak hanya memberikan pendapatan yang lumayan, lewat pengelolaan sampah yang baik, penguangan sampah yang ada menjadi lebih baik, dan bisa juga menikmati berbelanja di Waserda. BUMDes bisa saja membuat program lainnya, yang terpenting itu bisa membuat dan membangun kesejahteraan bagi 
penduduk dan warga desa yang ada dan tidak merugikan masyarakat. Bentuk partisipasi masyrakat dalam proses pengembangan ekonomi yang dilakukan oleh BUMDes yaitu:

a. Perencanaan

Perencanaan yang baik yaitu melibatkan masyarakat agar dibentuknya suatu program sesuai dengan apa yang di perlukan masyarakat. Dalam perencanaan ini, masyarakat harus tau secara detail tujuan dan langkah-langkah dari apa yang akan di lakukan oleh BUMDes. Apalagi BUMDes adalah badan usaha yang di haruskan ada di setiap Desa, jika masyarakat tidak dilibatkan dalam proses pembentukannya, hadirnya BUMDes akan sia-sia.

b. Pelaksanaan

Sasaran utamanya adalah masyrakat setempat. Jika masyarakat tidak ikut serta dalam kegiatan usaha yang sedang di kembangkan maka semuanya tidak akan terjalankan. Pada tahap ini, 50\% masyarakat Desa sudah mulai ikutu serta untuk meningkatkan unit usaha yang sudah berdiri. Masyarakat banyak yang menggunakan jasa dan produk yang dimiliki BUMDes seperti membayar listrik, menitip produknya ke warung BUMDes, dan lainnya. Partisipasi masyarakat didalam pelaksaan di mulai setelah di bentuknya perencanaan. Dalam pelaksaan ini, masyarakat ikut dalam pelatihan kewirausahaan yang di selenggarakan oleh BUMDes yang tujuannya adalah untuk memberikan masukan tentang pengelolaan usaha masyarakat setempat. Diharapkan masyarakat dapat mempercayai BUMDes untuk mengembangkan usaha mereka demi memajukan desa dan mensejahterkan masyarakat yang ada di Desa.

c. Monitoring dan Evaluasi

Mengawasi setiap kegiatan yang dilakukan desa adalah suatu kewajiban seluruh masyarakat desa. Maka partisipasi masyarakat dalam monitoring juga dibutuhkan agar kegiatan yang sudah berjalan bisa berlanjut dan tidak terjadi penyimpangan. Pada tahap ini masyarakat belum secara optimal, masyarakat belum mengerti bagaimana pengelolaan BUMDes yang sebenarnya. Sehingga, masyarakat tidak mengetahui setiap aliran dana desa yang sudah keluar, dan pemasukan desa dari setiap unit usaha BUMDes. Di karenakaninformasikurang di sosialisasikan kepada masyarakat. Jadi partisipasi masyarakat masih sangat kurang dalam membantu proses pengembangan ekonomi di desa, maka dari itu unit usaha yang di miliki BUMDes masih pasang surut dikarenakan kurangnya partisipasi masyarakat, yang dimana masyarakat tidak mengetahui apa yang dibuat oleh BUMDes.

Partisipasi masyarakat sangat di butuhkan dalam memajukan BUMDes, karena BUMDes bisa berjalan dengan baik apabila pengelolaan, pengawasan, dan partisipasi masyarakat bisa di lakukan dengan baik. Partisipasi masyarakat Desa Sidakarya juga sangat bagus, karena hampir seluruh masyarakat beralih ke BUMDes demi mendapatkan harga yang jauh lebih murah. Kedepannya, diharapkan BUMDes Sidakarya bisa membangun lebih banyak waserda di setiap pelosok Desa Sidakarya.

\section{SIMPULAN DAN SARAN}

\section{Simpulan}

Dalam implementasi pengelolaan BUMDes, ada tiga hal yang harus diperhatikan, yaitu tentang penguatan kapasitas pengelolaan BUMDes, laporan dan administrasi keuangan BUMDes, dan pengembangan unit usaha. Maka arah kebijakan pembinaan BUMDes berfokus pada upaya fasilitasi pengembangan SDM, penguatan kelembagaan, peningkatan akses modal, dan advokasi kebijakan yang dirumuskan berdasarkan skala prioritas. Kemudian, salah satu desa yang telah memiliki BUMDes adalah Desa Sidakarya. BUMDes sidakarya telah berkontribusi besar terhadap kesejahteraan masyarakat Desa. Hal ini dapat dilihat dari beberapa dampak positif yang dirasakan masyarakat desa, membantu masyarakat desa yang kekurangan modal untuk mengembangkan usaha dengan adanya program waserda, karena waserda memberikan harga yang lebih murah terhadap pedagang-pedagang kecil agar mendapatkan untung yang lebih banyak. Partisipasi masyarakat Desa terhadap BUMDes terbilang sudah aktif, terlihat pada partisipasi masyarakat terhadap perencanaan BUMDes, partisipasi dalam pelaksanaan BUMDes, dan pasrtisipasi dalam evaluasi kinerja BUMDes. Masyarakat Desa Sidakarya merasa di untungkan dengan hadirnya BUMDes karena telah banyak membantu masyarakat, sehingga secara sadar tanpa adanya paksaan, masyarakat ikut berpartisipasi dalam program maupun kegiatan-kegiatan BUMDes. 


\section{Saran}

Melalaui penelitian ini diharapkan agar BUMDes Sari Amreta Sudha dapat memberikan lapangan pekerjaan yang lebih banyak lagi bagi masyarakatnya. Selanjutnya, BUMDes Sari Amreta Sudha sebaiknya mengadakan sosialisasi menyeluruh kepada masyarakat Desa agar masyarakat dapat memahami banyaknya manfaat BUMDes yang akan di peroleh dari keikutsertaan terhadap program BUMDes dan pemerintah Desa di haruskan untuk lebih berperan aktif meningkatkan partisipasi masyarakat Desa terhadap program BUMDes.

\section{DAFTAR PUSTAKA}

Departemen Pendidikan Nasional Pusat Kajian Dinamika Sistem Pembangunan (PKDSP). (2007). Buku Panduan Pendirian dan Pengelolaan Badan Usaha Milik Desa (BUMDes). Jakarta: Fakultas Ekonomi Universitas Brawijaya.

Huda, N. (2015). Hukum Pemerintahan Desa dalam Konstitusi Indonesia Sejak Kemerdekaan Hingga era Reformasi. Malang: Setara Press.

Ishaq. (2017). Metode Penelitian Hukum \& Penulisan Skripsi, Tesis, Serta Disertasi. Bandung: Alfabeta.

Mubyarto, \& Kartodirdjo, S. (1988). Pembangunan Pedesaan di Indonesia. Liberty: Yogyakarta.

Poerwadarminta, W. J. S. (1975). Kamus Umum Bahasa Indonesia, Pusat Pembinaan Dan Pengembangan Bahasa. Jakarta: Departemen Pendidikan Dan Kebudayaan.

Soekanto, S. (1986). Pengantar Penelitian Hukum. Jakarta: Universitas Indonesia Press.

Soekanto, S. (2000). Sosiologi Suatu Pengantar. Jakarta: PT Raja Grafindo Persada.

Soekanto, S. (2008). Efektivitas Hukum Dan Penerapan Sanksi. Jakarta: PT Raja Grafindo Persada.

Sunggono, B. (2006). Metode Penelitian Hukum. Jakarta: Rajawali Pers.

Wijaya, D. (2018). BUMDESA: Badan Usaha Milik Desa. Yogyakarta: Gava Medi. 